\title{
Assessment of Some Basic Engineering Properties of Fibres Extracted from Thaumatococcus danielli Plant
}

\author{
Nurudeen Simbiat Adesola ${ }^{1}$, Lasisi Kayode Hassan ${ }^{1,}$,, Babatola Josiah Oladele ${ }^{1}$, Lafe Olurinde ${ }^{1,2}$ \\ ${ }^{1}$ Department of Civil Engineering, School of Engineering and Engineering Technology, Federal University of Technology, Akure, Nigeria \\ ${ }^{2}$ Centre for Renewable Energy and Technology, Federal University of Technology, Akure, Nigeria
}

Email address:

senserltd@gmail.com (K. H. Lasisi)

${ }^{*}$ Corresponding author

\section{To cite this article:}

Nurudeen Simbiat Adesola, Lasisi Kayode Hassan, Babatola Josiah Oladele, Lafe Olurinde. Assessment of Some Basic Engineering Properties of Fibres Extracted from Thaumatococcus danielli Plant. Machine Learning Research. Vol. 5, No. 1, 2020, pp. 1-9. doi: $10.11648 /$ j.mlr.20200501.11

Received: October 4, 2019; Accepted: January 31, 2020; Published: February 10, 2020

\begin{abstract}
The use of natural fibres either as reinforcement in polymer composites or as stand-alone material in engineering and construction is continuously gaining more attention. This study assesses some basic engineering properties of fibres extracted from thaumatococcus daniellii plant using topbond and evo-stik as adhesives. A total of 340 individual samples were weaved into sizes of $15 \mathrm{~cm}$ by $15 \mathrm{~cm}$ and glued together to a thickness of $2.5 \mathrm{~cm}$ from two fibre types of different texture and structure derived from thaumatococcus daniellii plant. Some of the samples were selected for alkali and acetylation treatments to improve their strength and were thereafter subjected to basic engineering tests such as water absorption, flexural strength, fire resistance and tensile strength tests. The test results show that the average water absorption rate of the treated materials glued with topbond for Material A possesses a lower percentage of $19.61 \%$ than $51.41 \%$ for treated materials glued with topbond for Material B. Material with evo-stik as adhesives has an extremely high water absorbing capacity. The average flexural strength of 103.50 Mpa for treated and topbond glued Material A is higher than $73.07 \mathrm{Mpa}$ for treated Material B and other untreated materials. Material A exhibits better fire resistance property than Material B, as it takes the latter longer time for ignition to occur during the test. Although, Material B give higher tensile strength values than Material A but with insignificant difference. The comparison between the two materials given due consideration to the adhesives used shows some correlation in their properties. However, Material A gives more satisfactory results than Material B hence making it the best choice of material from the two fibres extracted from the plant.
\end{abstract}

Keywords: Thaumatococcus daniellii, Adhesives, Water Absorption, Flexural Strength, Tensile Strength

\section{Introduction}

In recent times, there has been an increasing interest in the use of natural fibres as reinforcing components in fibre reinforced polymeric materials due to their enormous properties such as renewability, biodegradability, low density, low cost and environmentally friendliness [1]. The usage of fibres as reinforcement or as the main material in the construction industry is not a novel concept as it were. It has been used since ancient times. In the early 1900s, asbestos fibres were used in concrete, and in the 1950s the concept of composite materials came into being. By 1960 s, steel, glass, and synthetic fibres such as polypropylene fibres were used in concrete and as major materials in construction, and research into new fibres continues today [2].

Various types of fibres have been used, though, majorly in concrete to make it more strong, durable and economical. Natural fibres obtained from plants having physical and mechanical characteristics have great potentials in the development of engineering material. These fibres are easily available in large quantity and are also cheap. The advantage of using such fibres is that it provides generally a low cost construction and the elimination of the need for waste disposal. It also leads to an effective solid waste management technique [3-5]. Furthermore, the combination of interesting mechanical and physical properties, together with their environmentally friendly character has motivated a number 
of industrial sectors to consider these fibres as potential materials to replace synthetic fibres in environmentally safe products [1]. An interesting environmentally friendly alternative for the use of synthetic fibres as reinforcement in engineering composites are lignocellulosic natural fibres such as flax, jute and so on.

A number of investigations have been carried out to assess the potentials of natural fibers as reinforcements in polymers. Natural fiber reinforced polymer composites are increasingly being used for various engineering applications due to their numerous advantages. Many types of natural fibers have been investigated for use and they include flax, hemps, jute, straw, wood fiber, rice husk, wheat, barley, oats rye, cane (sugar and bamboo), grass reeds, kenaf, ramine, sisal, coir, water hyacinth, pennywort, kapok, paper-mulberry, raphia, banana fiber, pineapple leaf fiber and papyrus. They have the advantage of renewable resources and low cost [6-8]. Some countries like Pakistan and Malaysia which are solely agricultural dependent have used natural fibers in automotive and packaging materials. Although, natural fibres have gained wide range of application, there are however some bottlenecks associated with them, which have to be tackled before they can be employed in polymer composites or used as a standalone material [9]. Natural fibres especially plant fibres (seed hairs, flax, hemp, sisal) are hydrophilic as they are derived from lignocelluloses, which contain strongly polarized hydroxyl groups. The major limitations of using these fibres as reinforcements in matrices include poor interfacial adhesion between polar hydrophilic fibres and non-polar-hydrophilic matrix [10].

Thaumatococcus daniellii is a monocotyledonous plant found in rain forests and coastal areas of West and Central Africa [11, 12]. This plant is a large rhizomatous flowering herb which grows to about $3-4$ metres in height with large papery leaves [13]. It bears pale purple flowers and a soft crimson coloured fruit containing a few shiny black seeds. It is commonly referred to as the miraculous fruit, miraculous berry, serendipity berry and katempfe but in Nigeria, it is popular referred to as softcane [14]. It was one of the underutilized and neglected plant species in Nigeria, which grows wildly mainly in cocoa- growing areas of Southwest Nigeria [15]. It is categorized as a non-woody fibre plant used as supplement to wood fibre in paper manufacturing [16]. The plant, commonly known as "ewe eran" in Southwest Nigeria, is popular for being the natural source of thaumatin, a globally traded protein sweetener $[17,18]$. This low-calorie sweetner is about 2000 times sweeter than sucrose and suitable for diabetic patients [19].

Several works have been done on thaumatococcus daniellii plant by various researchers as cited above but more in the agricultural science perspectives. Only few works have been conducted on the fibres that can be extracted from the plant. The underutilization of this plant especially in engineering applications has therefore motivated this research. This research therefore seeks to assess some basic engineering properties of thaumatococcus daniellii plant fibres using two locally available adhesives.

\section{Materials and Methods}

The major materials used for this research are fibres from the outer part of thaumatococcus danielli plant (stem and pulp) and adhesives (Top bond gum and Evo-Stik). Other materials and equipment used include digital weighing balance, universal testing machine, furnace, desiccator, washing bowls and meter rule. The thaumatococcus danielli plant was acquired from local mat weavers in Ogotun Ekiti, Nigeria while the two adhesives used were procured at a local market in Akure, Nigeria. Figure 1 shows the two fibres extracted from the plant while Figure 2 shows the stalks harvested from the plant.

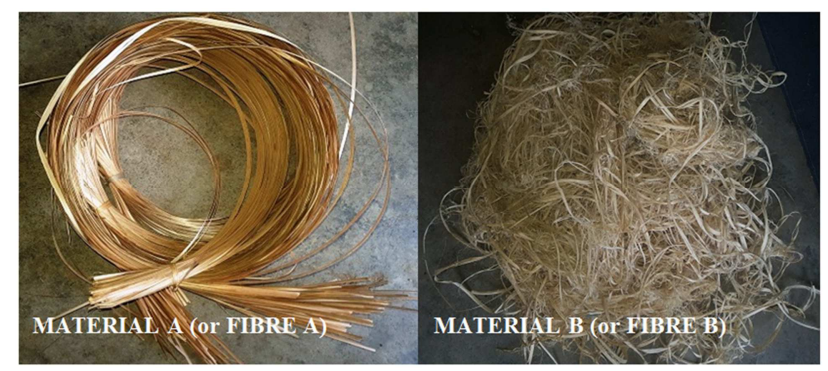

Figure 1. Fibres extracted from Thaumatococcus Danielli plant.

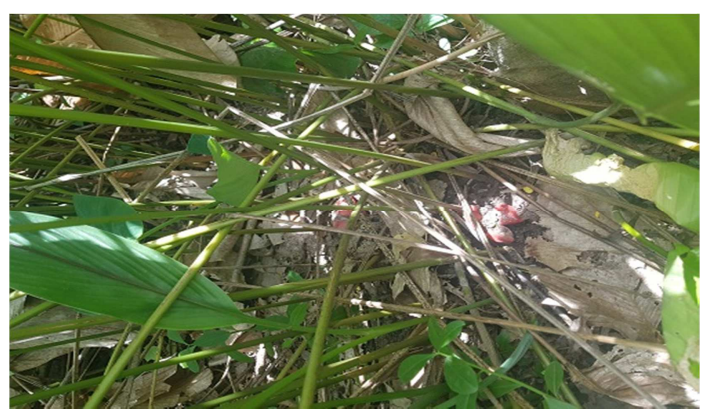

Figure 2. Thaumatococcus Danielli stalks harvested from the plant

\subsection{Description and Selection of Adhesives}

The affordability and availability of Top Bond Gum and Evo-Stik informed their choice for this research. Also, several works have been carried out by researchers on other types of adhesives (natural and artificial, organic and inorganic) like starch, gum arabic and so on. Top bond is a white high-quality water-based adhesive generally use to bond leather, rubber, canvas, paper, plastic, glass, wood, metal and sometimes concrete materials. It is usually packaged in different forms and shapes but the most common of it is the one sealed in cylindrical containers. Other forms of top bond may be tube-like or spray-like shape. Evo-stik is a hydrocarbon-based adhesive which has a dark yellowish colour. It is a general purpose, one part, synthetic, rubber/resin contact adhesive, particularly suitable for bonding decorative laminated plastic sheets, and other rigid plastics sheets (e.g. PVC and ABS), to wood, metal and all types of boards, except bituminous materials. It may also be used to bond boards of insulating fibre and cane fibre, rigid polyurethane foam, laminated panels and acoustic tiles to suspended or vertical surfaces such as flat-surfaced ceilings 
or walls. Just like top bond, Evo-Stik is usually packaged in different forms and shapes with the most common of it sealed in cylindrical containers. Figure 3 shows the two adhesives in their containers as packaged by the manufacturer.
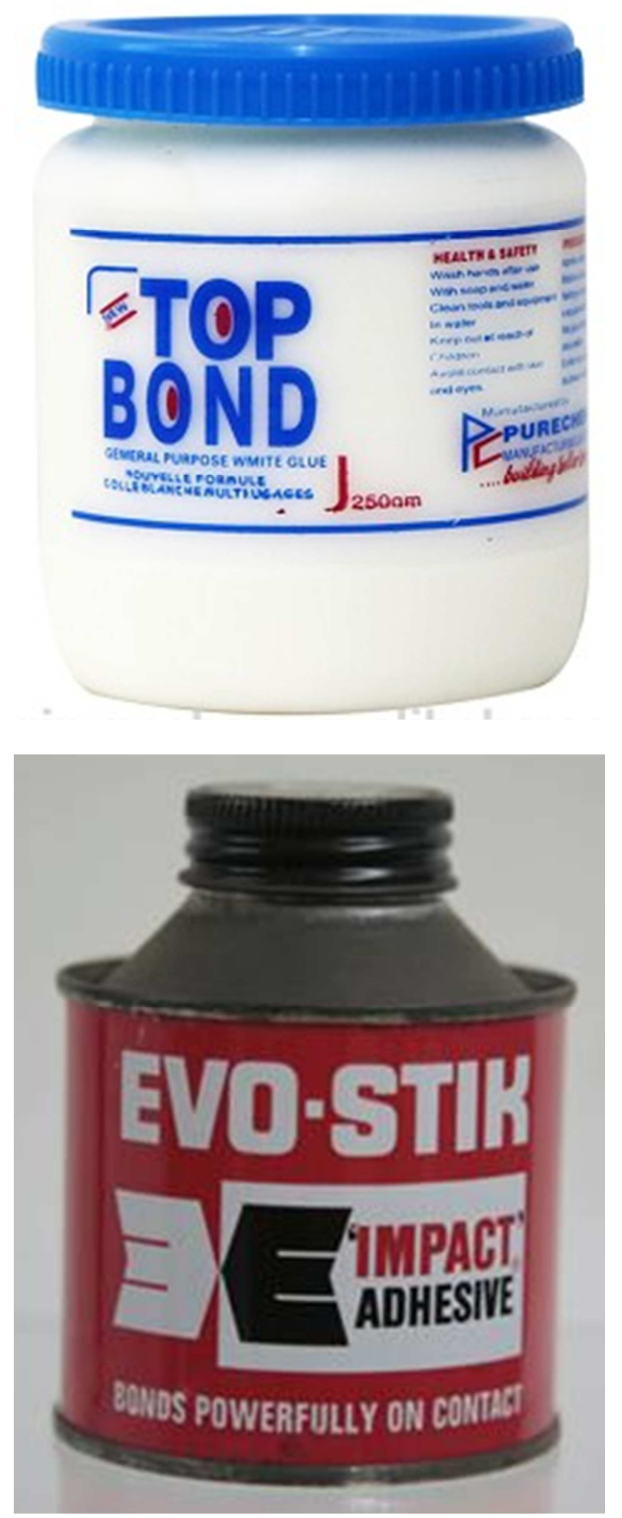

Figure 3. Topbond and Evo-Stik Adhesives Packaged in Containers [20].

\subsection{Preparation of Materials}

After collection of the plant was done, the petiole containing the fibres of two different fineness, were extracted and arranged. Two major sample types of the petiole were weavable and they were thus labeled as Material A and Material B for easy identification purpose. Weavers who specialize in mat weaving (most of which are indigene of the plant's origin) were hired to weave Material A with maximum supervision. It was further processed by cutting the weaved material into size of $30 \mathrm{~cm}$ by $30 \mathrm{~cm}$ after which $7.5 \mathrm{~cm}$ strands in thickness was removed from each sides of the mat to give $15 \mathrm{~cm}$ by $15 \mathrm{~cm}$ in order to give suitable allowance for knotting. All the sides were knotted to secure the strands from removing and the edges were trimmed off to make them neat. A total of 240 samples were weaved for Material A. Material B was also hand-weaved into size of 15 $\mathrm{cm}$ by $15 \mathrm{~cm}$, the four sides were also knotted, and all the edges were trimmed off. A total of 100 samples were weaved for Sample Type B. The overall weaving procedures followed the procedure adopted by [21].

\subsection{Chemical Treatment of Materials}

To further improve the quality of the materials, some were treated using the alkali treatment method (also known as mercerization) and the acetylation method. Both treatments were carried out following the method reported by [22]. For the alkali treatment method, $10 \%$ of Sodium hydroxide $(\mathrm{NaOH})$ solution was used to soak weaved materials at temperature of $30^{\circ} \mathrm{C}$ for one hour. The materials were then removed from the $\mathrm{NaOH}$ solution and washed thoroughly with distilled water to remove excess $\mathrm{NaOH}$.

For the acetylation treatment, clean weaved materials were first soaked in $5 \% \mathrm{NaOH}$ solution for one hour at $30^{\circ} \mathrm{C}$. Then, they were decanted and soaked in glacial acetic acid for another one hour at $30^{\circ} \mathrm{C}$. Thereafter, the materials were decanted and finally soaked in acetic anhydride containing few drops of concentrated $\mathrm{H}_{2} \mathrm{SO}_{4}$ for 5 minutes at the same temperature. The treated fibres were finally air-dried for 30 minutes to drain off the moisture present.

Gluing of Sample Materials

After treatment, the samples were glued together using the two adhesives by stacking on one another and gluing to achieve a thickness of $2.5 \mathrm{~cm}$ for each of the material types. It was thereafter subject under a load of 300 Newton for 24 hours to allow for a very stiff bonding.

Basic Engineering Tests

To assess the engineering properties of the two materials type, some basic tests which include moisture content, dry density, water absorption, flexural strength, fire resistance and tensile strength tests were carried out.

The moisture content was determined by initially weighing the glued samples to get their initial weight $\left(\mathrm{W}_{1}\right)$. The samples were then sun-dried at a temperature range of $35^{\circ} \mathrm{C}$ to $40^{\circ} \mathrm{C}$ for 24 hours and then weighed to obtain the dried weight $\left(\mathrm{W}_{2}\right)$. The percentage moisture content was thereafter computed using Equation 1.

$$
\% \text { Moisture Content }=\frac{W_{1}-W_{2}}{W_{1}} \times 100
$$

The density of the fibre was determined according to [23]. It was determined by the ratio of mass of each weaved fibre to the volume of each specimen. The formula used is shown in Equation 2.

$$
\text { Dry Density }=\frac{\text { Mass }(g)}{\text { Volume }\left(\mathrm{cm}^{3}\right)}
$$

To determine the amount of water absorbed by both material types under specified conditions, three treated and untreated samples of each material were initially oven dried for 6 hours at a controlled temperature of $30^{\circ} \mathrm{C}$ and then 
placed in a desiccator to cool. This was done to remove the natural moisture entrapped in the samples. Immediately upon cooling, the samples were weighed as $\mathrm{M}_{1}$ and then immersed in water at room temperature ranging between $23^{\circ} \mathrm{C}$ and $27^{\circ} \mathrm{C}$ for 12 hours until equilibrium was physically observed in the rate of water absorbed. Specimens were removed, patted dry with a lint free cloth, and weighed as $\mathrm{M}_{2}$. The water absorption was computed using Equation 3 expressed as increase in weight percent.

$$
\frac{M_{2}-M_{1}}{M_{1}} \times 100 \%
$$

Flexural tests were conducted according to [24] to determine the flexural properties of the samples (both treated and untreated). Universal testing machine (Instron 5960, 30 $\mathrm{kN}$ load cell) was used to carry out a uniformly distributed bending tests and a crosshead speed of $2 \mathrm{~mm} / \mathrm{min}$. A total of twelve (12) weaved rectangular samples were tested with three (3) specimens of dimension $150 \mathrm{~mm} \times 150 \mathrm{~mm} \times 25$ $\mathrm{mm}$ for each case. During the application of load, the samples were compressed until shrinkage was observed in the materials. The values for flexural strength were then calculated using Equation 4.

$$
\mathrm{F}_{\mathrm{o}}=\frac{1.5 p l}{b t^{2}}
$$

Where:

$\mathrm{F}_{\mathrm{o}}$ is the Flexural Strength

$\mathrm{P}$ is the load at break

1 is the length of sample

$b$ is the breadth of sample; and

$t$ is the depth of the sample

Fire resistance test was carried out to determine the effect of heat on the samples in accordance with [25]. This test measures and describes the response of the material to heat and flame under controlled conditions. The two materials (under the category of treated and untreated) were placed separately in furnace with working space dimension of 300 $\mathrm{mm}$ by $200 \mathrm{~mm}$ by $120 \mathrm{~mm}$ and were powered with output voltage of $220 \mathrm{~V}$ and current of $8 \mathrm{~A}$ for application of heat. The ignition time was finally calculated.

Tensile test was conducted according to [26] using INSTRON 3369 Universal Testing Machine with maximum load of $50 \mathrm{KN}$. The test was performed at a crosshead speed of $5 \mathrm{~mm} / \mathrm{min}$. Six (6) samples in total were tested with Materials A and B having three samples each. After placing the sample into the machine, load was uniformly applied at both ends. As the load is gradually been applied, a break occurred on the sample (Figure 4). The results and graphs obtained were recorded and plotted by the machine.
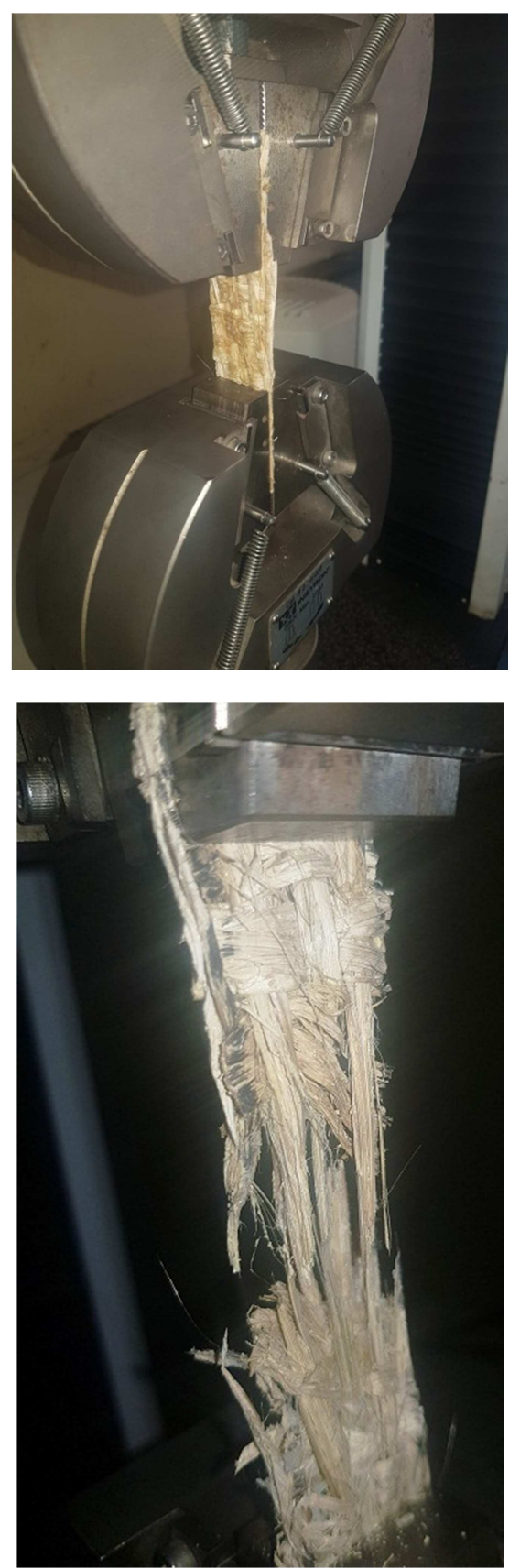

Figure 4. Material under tensile loading and breaking after load application.

\section{Results and Discussion}

The results of the moisture content and density of the two materials are presented in Tables 1 and 2 .

\begin{tabular}{|c|c|c|c|c|c|c|}
\hline \multirow{2}{*}{ Parameters } & \multicolumn{3}{|c|}{ Material A } & \multicolumn{3}{|c|}{ Material B } \\
\hline & Sample 1 & Sample 2 & Sample 3 & Sample 1 & Sample 2 & Sample 3 \\
\hline Initial weight $\left(\mathrm{W}_{1}\right)$ in $\mathrm{g}$ & 204 & 198 & 202 & 185 & 190 & 188 \\
\hline Final weight $\left(\mathrm{W}_{2}\right)$ in $\mathrm{g}$ & 185 & 181 & 184 & 165 & 168 & 167 \\
\hline Weight of Moisture $\left(\mathrm{W}_{3}\right)$ in $\mathrm{g}$ & 19 & 17 & 18 & 20 & 22 & 21 \\
\hline$\%$ Weight of Moisture & 9.31 & 8.59 & 8.91 & 11.58 & 11.58 & 11.17 \\
\hline Average $(\%)$ & 8.94 & & & 11.19 & & \\
\hline
\end{tabular}

Table 1. Moisture Content Test Result for Materials A and B. 
From Tables 1, the average percentage water content results for both fibres $\mathrm{A}$ and $\mathrm{B}$ give $8.94 \%$ and $11.19 \%$ respectively. These values fall within the permissible range of values $1-25 \%$ provided in [27]. Hence, both materials type show indication of suitable acceptability. The average density results of all the samples before and after sun drying are presented in Table 2 .

Table 2. Density Results for Fibres A and B before Sun Drying.

\begin{tabular}{lllll}
\hline Material Designation for Fibres & Mass $(\mathbf{M})$ in $\mathbf{g}$ & Volume $(\mathbf{V})$ in $\mathbf{c m}^{\mathbf{3}}$ & Dry Density $(\mathbf{D})$ in $\mathbf{g} / \mathbf{c m}^{\mathbf{3}}$ & ${\text { Average Dry Density in } \mathbf{g} / \mathbf{c m}^{\mathbf{3}}}$ \\
\hline Density before sun drying & & & & \\
A1 & 204 & 562.50 & 0.36 & 0.36 \\
A2 & 198 & 562.50 & 0.35 & \\
A3 & 202 & 562.50 & 0.36 & 0.34 \\
B1 & 185 & 551.25 & 0.34 & \\
B2 & 190 & 551.25 & 0.34 & \\
B3 & 188 & 551.25 & 0.34 & 0.33 \\
Density after sun drying & & & & \\
A1 & 185 & 562.50 & 0.33 & 0.30 \\
A2 & 181 & 562.50 & 0.32 & \\
A3 & 184 & 562.50 & 0.33 & \\
B1 & 165 & 551.25 & 0.30 & \\
B2 & 168 & 551.25 & 0.30 & \\
B3 & 167 & 551.25 & 0.30 & \\
\hline
\end{tabular}

The percentage change in density $($ Fibre $A)=\frac{0.36-0.33}{0.36} \times$ $100=8.33 \%$

The percentage change in density $($ Fibre $B)=\frac{0.34-0.30}{0.34} \times$ $100=11.77 \%$

The average dry density results for both fibres A and B before and after sun drying were both calculated, to give the percentage change in densities of the two fibres. The results give $8.33 \%$ and $11.77 \%$ respectively. These results are appropriate as they fall within the permissible range of values provided in [23] for similar fibre material.

\subsection{Water Absorption}

Tables 3 and 4 show the results obtained for both treated and untreated materials glued with topbond and evo-stik. The average water absorption rate obtained for the treated and untreated samples of both materials are shown in Figures 5 and
6. From the results, the treated Material A for both adhesives possesses lower water absorption rates when compared with treated Material B. This may be as a result of the effect of chemical treatment carried out on some samples of Material A and $\mathrm{B}$ which serves as inhibitor for water to be absorbed. The same trend was also observed in the untreated material of both samples. On the other hand, the untreated material for both adhesives possesses high water absorption rates when compared with treated material. This increase may be as a result of the tiny petiole matrix content present in Material B. This further signifies that more water can be absorbed. However, the overall values for the material of both A and B for Evo-Stik gum are higher than the ones for Topbond gum. Therefore, Topbond glued materials can be taken as the most optimum sample that has great tendencies for better performance during usage.

Table 3. Water absorption test results for treated and untreated Material A.

\begin{tabular}{llllll}
\hline Sample No & Dry $\left(\mathbf{M}_{\mathbf{1}}\right)$ in $\mathbf{g}$ & Wet $\left(\mathbf{M}_{\mathbf{2}}\right)$ in $\mathbf{g}$ & Difference $\left(\mathbf{M}_{\mathbf{2}}-\mathbf{M}_{\mathbf{1}}\right)$ in $\mathbf{g}$ & \% Water Absorption & Average\% Water Absorption \\
\hline \multicolumn{2}{l}{ Glued with top bond } & & & & \\
$\mathrm{A}_{\mathrm{T} 1}$ & 180 & 217 & 37 & 20.55 & 18.18 \\
$\mathrm{~A}_{\mathrm{T} 2}$ & 176 & 208 & 32 & 20.11 & \\
$\mathrm{~A}_{\mathrm{T} 3}$ & 179 & 215 & 36 & 28.88 & \\
$\mathrm{~A}_{\mathrm{UT} 1}$ & 187 & 241 & 54 & 26.37 & 28.20 \\
$\mathrm{~A}_{\mathrm{UT2}}$ & 182 & 230 & 48 & 29.35 & \\
$\mathrm{~A}_{\mathrm{UT3}}$ & 184 & 238 & 54 & & \\
Glued with Evo-stik & & & 24.29 & \\
$\mathrm{~A}_{\mathrm{T} 1}$ & 177 & 220 & 43 & 21.84 & \\
$\mathrm{~A}_{\mathrm{T} 2}$ & 174 & 212 & 38 & 23.33 & \\
$\mathrm{~A}_{\mathrm{T} 3}$ & 180 & 222 & 42 & 32.24 & 31.77 \\
$\mathrm{~A}_{\mathrm{UT} 1}$ & 183 & 242 & 59 & 29.73 & 33.33 \\
$\mathrm{~A}_{\mathrm{UT2}}$ & 185 & 240 & 55 & 62 & \\
$\mathrm{~A}_{\mathrm{UT} 3}$ & 186 & 248 & &
\end{tabular}

NOTE: $\mathrm{A}_{\mathrm{T} 1}, \mathrm{~A}_{\mathrm{T} 2}$ and $\mathrm{A}_{\mathrm{T} 3}$ denote Sample 1, 2 and 3 of Treated Fibres $\mathrm{A}$ while $\mathrm{A}_{\mathrm{UT} 1}, \mathrm{~A}_{\mathrm{UT} 2}$ and $\mathrm{A}_{\mathrm{UT} 3}$ denote Sample 1, 2 and 3 of Untreated Fibres A respectively. 
Table 4. Water absorption test results for treated and untreated Material B.

\begin{tabular}{|c|c|c|c|c|c|}
\hline Sample No & Dry $\left(M_{1}\right)$ in $g$ & Wet $\left(\mathbf{M}_{2}\right)$ in $\mathrm{g}$ & Difference $\left(M_{2}-M_{1}\right)$ in $g$ & \% Water Absorption & Average\% Water Absorption \\
\hline \multicolumn{6}{|c|}{ Glued with top bond } \\
\hline $\mathrm{B}_{\mathrm{T} 1}$ & 163 & 246 & 83 & 50.92 & \multirow{3}{*}{51.41} \\
\hline $\mathrm{B}_{\mathrm{T} 2}$ & 162 & 240 & 78 & 48.15 & \\
\hline $\mathrm{B}_{\mathrm{T} 3}$ & 165 & 256 & 91 & 55.15 & \\
\hline $\mathrm{B}_{\mathrm{UT1}}$ & 167 & 263 & 96 & 57.49 & \multirow{3}{*}{58.61} \\
\hline $\mathrm{B}_{\mathrm{UT} 2}$ & 170 & 271 & 101 & 59.41 & \\
\hline $\mathrm{B}_{\text {UT3 }}$ & 168 & 267 & 99 & 58.93 & \\
\hline \multicolumn{6}{|c|}{ Glued with Evo-stik } \\
\hline $\mathrm{B}_{\mathrm{T} 1}$ & 168 & 248 & 80 & 47.62 & \multirow{3}{*}{53.74} \\
\hline $\mathrm{B}_{\mathrm{T} 2}$ & 163 & 252 & 89 & 54.60 & \\
\hline $\mathrm{B}_{\mathrm{T} 3}$ & 161 & 256 & 95 & 59.00 & \\
\hline $\mathrm{B}_{\mathrm{UT1}}$ & 172 & 276 & 104 & 60.47 & \multirow{3}{*}{60.30} \\
\hline $\mathrm{B}_{\mathrm{UT} 2}$ & 175 & 283 & 108 & 61.71 & \\
\hline $\mathrm{B}_{\mathrm{UT3}}$ & 172 & 273 & 101 & 58.72 & \\
\hline
\end{tabular}

NOTE: $\mathrm{B}_{\mathrm{T} 1}, \mathrm{~B}_{\mathrm{T} 2}$ and $\mathrm{B}_{\mathrm{T} 3}$ denote Sample 1, 2 and 3 of Treated Fibres $\mathrm{B}$ while $\mathrm{B}_{\mathrm{UT1}}, \mathrm{B}_{\mathrm{UT2} 2}$ and $\mathrm{B}_{\mathrm{UT} 3}$ denote Sample 1, 2 and 3 of Untreated Fibres B respectively.

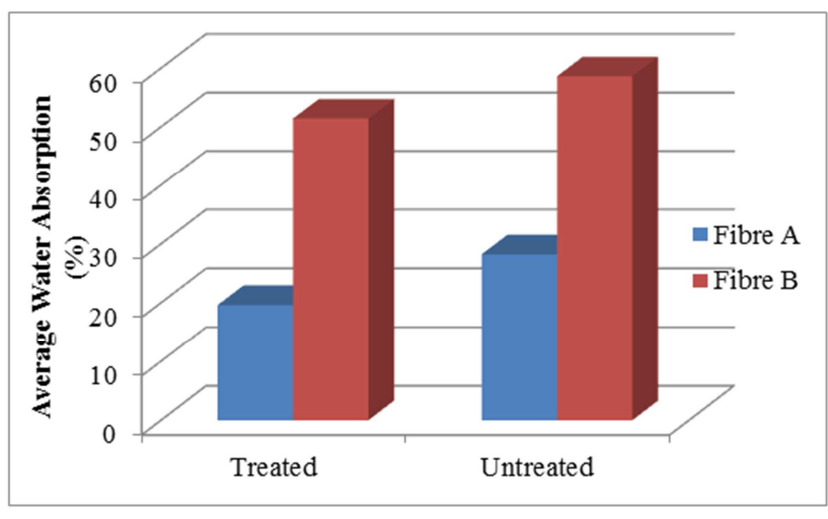

Figure 5. Percentage water absorption for both samples of topbond gum.

\subsection{Flexural Strength Test Result}

Tables 5 and 6 show the flexural strength results obtained for both the treated and untreated materials glued with topbond and evo-stik. The length, width and height of the two materials remain constant throughout the test with dimension $150 \times 150$ $\times 25 \mathrm{~mm}$. It was observed from the results obtained that the average flexural strength is higher for treated materials of both Materials A and B than for the untreated of Materials A and B. This observation may be as a result of the acetylation treatment carried out on the samples as chemical treatment has been found out by $[8,22]$ to increase the performance of fibre under bending force and moment.

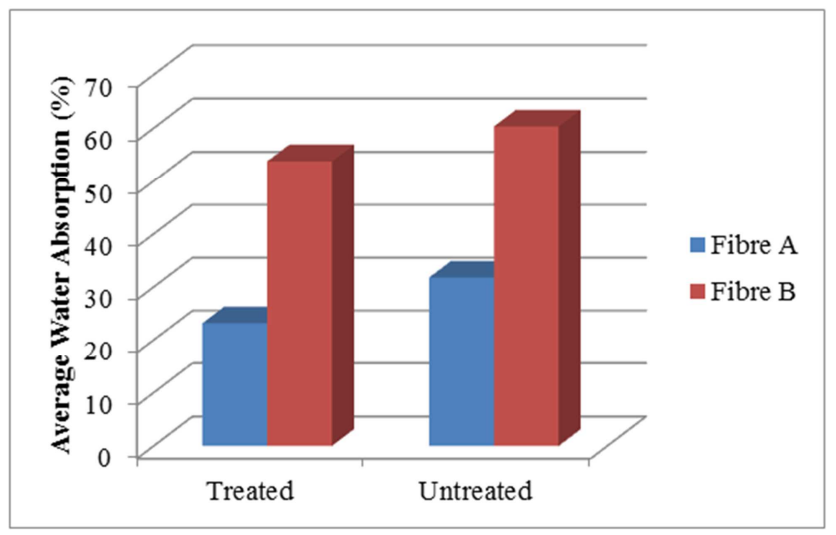

Figure 6. Percentage Water Absorption of both Samples for Evo-Stik Gum.

Table 5. Flexural strength test results for treated and untreated Material A.

\begin{tabular}{|c|c|c|c|c|c|c|c|}
\hline Sample No & $\begin{array}{l}\text { Load at Break } \\
(P) \text { in } k N\end{array}$ & $\begin{array}{l}\text { Flexural Strength } \\
\frac{1.5 p l}{b t^{2}} \text { in MPa }\end{array}$ & $\begin{array}{l}\text { Average } \\
\text { Flexural } \\
\text { Strength }\end{array}$ & $\begin{array}{l}\text { Sample } \\
\text { No }\end{array}$ & $\begin{array}{l}\text { Load at Break (P) } \\
\text { in } \mathrm{kN}\end{array}$ & $\begin{array}{l}\text { Flexural Strength } \\
\frac{1.5 p l}{b t^{2}} \text { in MPa }\end{array}$ & $\begin{array}{l}\text { Average } \\
\text { Flexural } \\
\text { Strength }\end{array}$ \\
\hline \multicolumn{4}{|c|}{ Glued with Topbond } & \multicolumn{4}{|c|}{ Glued with Evo-stik } \\
\hline $\mathrm{A}_{\mathrm{T} 1}$ & 55 & 133.35 & \multirow{3}{*}{129.25} & $\mathrm{~A}_{\mathrm{T} 1}$ & 47 & 112.80 & \multirow{3}{*}{109.60} \\
\hline$A_{T 2}$ & 54 & 129.60 & & $\mathrm{~A}_{\mathrm{T} 2}$ & 44 & 105.60 & \\
\hline $\mathrm{A}_{\mathrm{T} 3}$ & 52 & 124.80 & & $\mathrm{~A}_{\mathrm{T} 3}$ & 46 & 110.40 & \\
\hline $\mathrm{A}_{\mathrm{UT1} 1}$ & 49 & 117.60 & \multirow{3}{*}{113.60} & $\mathrm{~A}_{\mathrm{UT1}}$ & 41 & 98.40 & \multirow{3}{*}{97.60} \\
\hline $\mathrm{A}_{\text {UT2 }}$ & 45 & 108.00 & & $\mathrm{~A}_{\mathrm{UT2}}$ & 39 & 93.60 & \\
\hline AUT3 $_{1}$ & 48 & 115.20 & & АUt3 & 42 & 100.80 & \\
\hline
\end{tabular}

NOTE: $A_{T 1}, A_{T 2}$ and $A_{T 3}$ denote Sample 1, 2 and 3 of Treated Fibres A while $A_{U T 1}, A_{U T 2}$ and $A_{U T 3}$ denote Sample 1, 2 and 3 of Untreated Fibres A respectively.

Table 6. Flexural strength test results for treated and untreated Material B.

\begin{tabular}{|c|c|c|c|c|c|c|c|}
\hline Sample No & $\begin{array}{l}\text { Load at Break } \\
(P) \text { in } k N\end{array}$ & $\begin{array}{l}\text { Flexural Strength } \\
\frac{1.5 p l}{b t^{2}} \text { in MPa }\end{array}$ & $\begin{array}{l}\text { Average } \\
\text { Flexural } \\
\text { Strength } \\
\end{array}$ & $\begin{array}{l}\text { Sample } \\
\text { No }\end{array}$ & $\begin{array}{l}\text { Load at Break } \\
\text { (P) in } k N\end{array}$ & $\begin{array}{l}\text { Flexural Strength } \\
\frac{1.5 p l}{b t^{2}} \text { in MPa }\end{array}$ & $\begin{array}{l}\text { Average Flexural } \\
\text { Strength }\end{array}$ \\
\hline \multicolumn{4}{|c|}{ Glued with Topbond } & \multicolumn{4}{|c|}{ Glued with Evo-stik } \\
\hline $\mathrm{B}_{\mathrm{T} 2}$ & 63 & 151.20 & 155.20 & $\mathrm{~B}_{\mathrm{T} 2}$ & 59 & 141.60 & 142.40 \\
\hline $\mathrm{B}_{\mathrm{T} 3}$ & 67 & 160.80 & & $\mathrm{~B}_{\mathrm{T} 3}$ & 61 & 146.40 & \\
\hline $\mathrm{B}_{\mathrm{UT1}}$ & 61 & 146.4 & 135.20 & $\mathrm{~B}_{\mathrm{UT} 1}$ & 53 & 127.20 & 123.20 \\
\hline
\end{tabular}




\begin{tabular}{|c|c|c|c|c|c|c|c|}
\hline Sample No & $\begin{array}{l}\text { Load at Break } \\
\text { (P) in } k N\end{array}$ & $\begin{array}{l}\text { Flexural Strength } \\
\frac{1.5 p l}{b t^{2}} \text { in MPa }\end{array}$ & $\begin{array}{l}\text { Average } \\
\text { Flexural } \\
\text { Strength }\end{array}$ & $\begin{array}{l}\text { Sample } \\
\text { No }\end{array}$ & $\begin{array}{l}\text { Load at Break } \\
\text { (P) in kN }\end{array}$ & $\begin{array}{l}\text { Flexural Strength } \\
\frac{1.5 p l}{b t^{2}} \text { in MPa }\end{array}$ & $\begin{array}{l}\text { Average Flexural } \\
\text { Strength }\end{array}$ \\
\hline $\mathrm{B}_{\mathrm{UT} 2}$ & 56 & 134.4 & & $\mathrm{~B}_{\text {UT2 }}$ & 50 & 120.00 & \\
\hline $\mathrm{B}_{\mathrm{UT3}}$ & 52 & 124.8 & & $\mathrm{~B}_{\mathrm{UT3}}$ & 51 & 122.40 & \\
\hline
\end{tabular}

NOTE: $\mathrm{B}_{\mathrm{T} 1}, \mathrm{~B}_{\mathrm{T} 2}$ and $\mathrm{B}_{\mathrm{T} 3}$ denote Sample 1, 2 and 3 of Treated Fibres $\mathrm{B}$ while $\mathrm{B}_{\mathrm{UT} 1}$, $\mathrm{B}_{\mathrm{UT} 2}$ and $\mathrm{B}_{\mathrm{UT} 3}$ denote Sample 1, 2 and 3 of Untreated Fibres B respectively.

\subsection{Fire Resistance Test Results}

Tables 7 and 8 show the fire resistance results obtained for both the treated and untreated materials glued with topbond and evo-stik. The key parameters include the ignition time, ignition temperature and the thermal conductivity. From the results, that materials glued with Evo-Stik possess low ignition time and temperature when compared with those glued with Topbond. This is owing to the fact that, Evo-stik adhesives was made from petroleum materials containing some hydrocarbons which makes the materials highly and readily flammable. Also, the chemical treatment also contributed to the elongated ignition time as the molecular bonding of the treated materials are enhanced and cannot be broken down easily by the application of heat. The ignition temperature was observed to be directly proportional to the ignition time thereby showing a linear relationship.

Table 7. Results of Fire Resistance Test of Material A for Topbond and Evo-stik.

\begin{tabular}{lllll}
\hline \multirow{2}{*}{ Parameters } & Glued with Topbond & & Glued with Evo-stik \\
\cline { 2 - 5 } & Treated & Untreated & Treated & Untreated \\
\hline Ignition Time $(\mathrm{sec})$ & 946 & 895 & 759 & 616 \\
Ignition Temperature $\left({ }^{\circ} \mathrm{C}\right)$ & 234 & 205 & 173 & 158 \\
Thermal Conductivity $(\mathrm{W} / \mathrm{mk})$ & 0.15 & 0.16 & 0.13 & 0.12 \\
\hline
\end{tabular}

Table 8. Results of Fire Resistance Test of Material B for Topbond and Evo-stik.

\begin{tabular}{lllll}
\hline \multirow{2}{*}{ Parameters } & Glued with Topbond & & Glued with Evo-stik \\
\cline { 2 - 5 } & Treated & Untreated & Treated & Untreated \\
\hline Ignition Time $(\mathrm{sec})$ & 868 & 749 & 686 & 515 \\
Ignition Temperature $\left({ }^{\circ} \mathrm{C}\right)$ & 220 & 194 & 168 & 151 \\
Thermal Conductivity $(\mathrm{W} / \mathrm{mk})$ & 0.15 & 0.16 & 0.13 & 0.12 \\
\hline
\end{tabular}

\subsection{Tensile Test Results}

The tensile test results as produced by the universal testing machine used are presented in Table 9 with their corresponding stress-strain curve shown in Figures 7 to 12.

Table 9. Tensile stress and strain results for the two materials.

\begin{tabular}{llll}
\hline Sample No & Tensile stress at Yield (Zero Slope) (MPa) & Extension at Break (Standard) (mm) & Reduction of Area at Area Reduction (\%) \\
\hline A1 & 16.77138 & 188.65028 & 95.12195 \\
A2 & 18.71247 & 154.74044 & 92.06349 \\
A3 & 36.27392 & 135.59982 & 88.63636 \\
B1 & 2.60272 & 184.04560 & 97.22222 \\
B2 & 5.41625 & 118.15014 & 94.70899 \\
B3 & 3.99638 & 81.02389 & 90.90909 \\
\hline
\end{tabular}

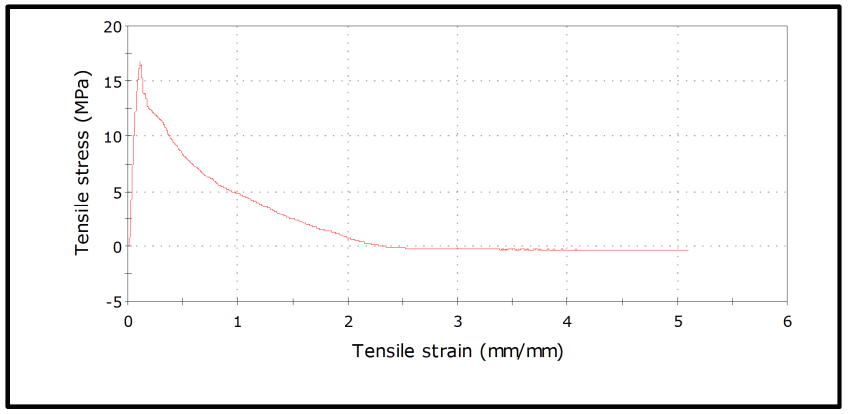

Figure 7. Stress-Strain Curve for Fibre A1.

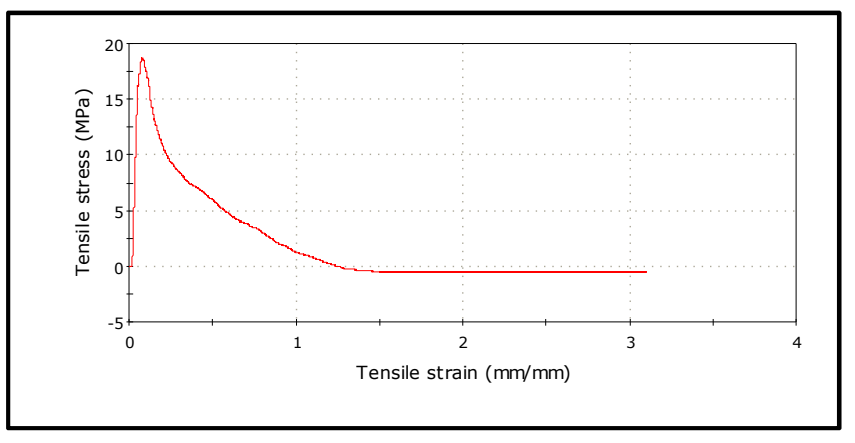

Figure 8. Stress-Strain Curve for Fibre A2. 


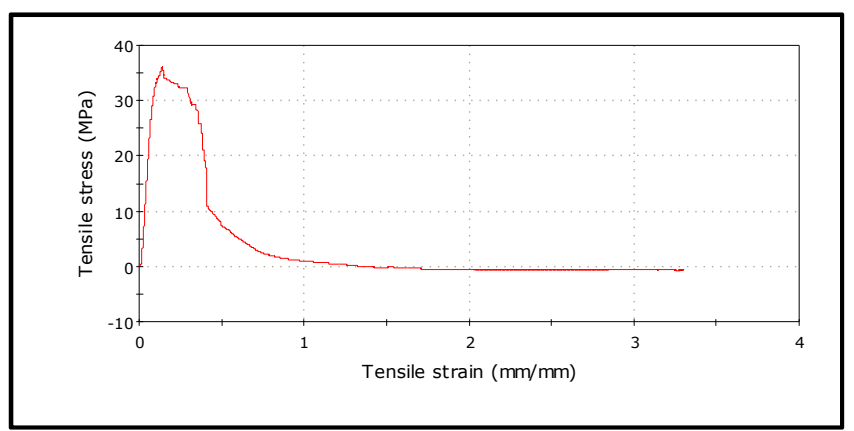

Figure 9. Stress-Strain Curve for Fibre A3.

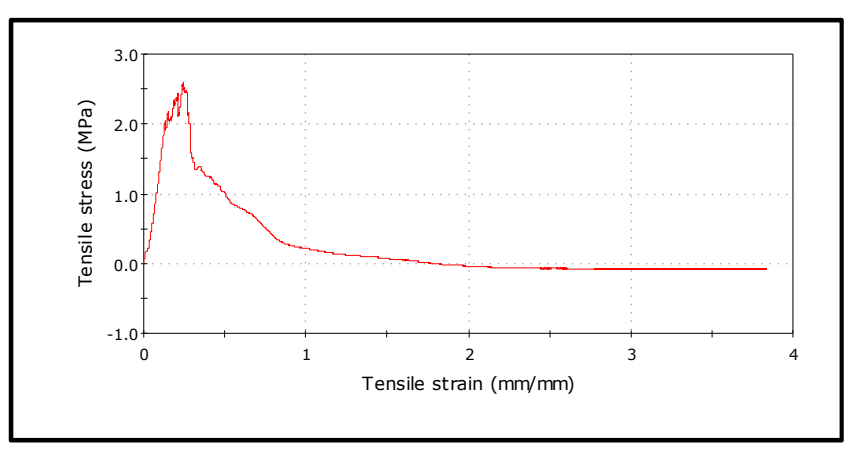

Figure 10. Stress-Strain Curve for Fibre B1.

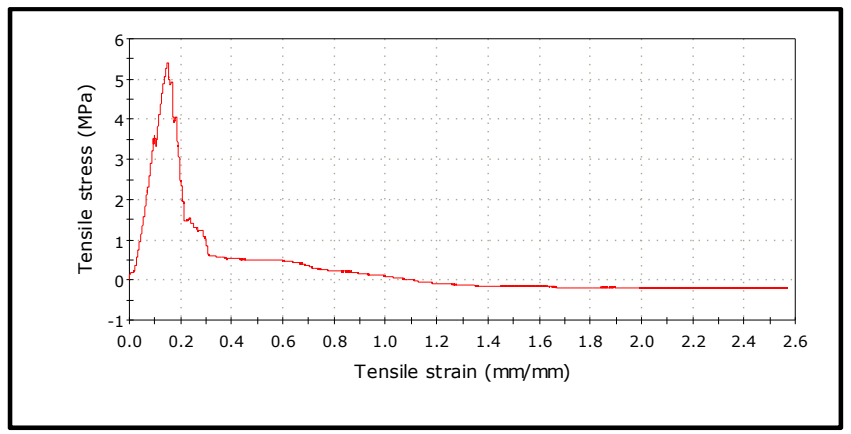

Figure 11. Stress-Strain Curve for Fibre B2.

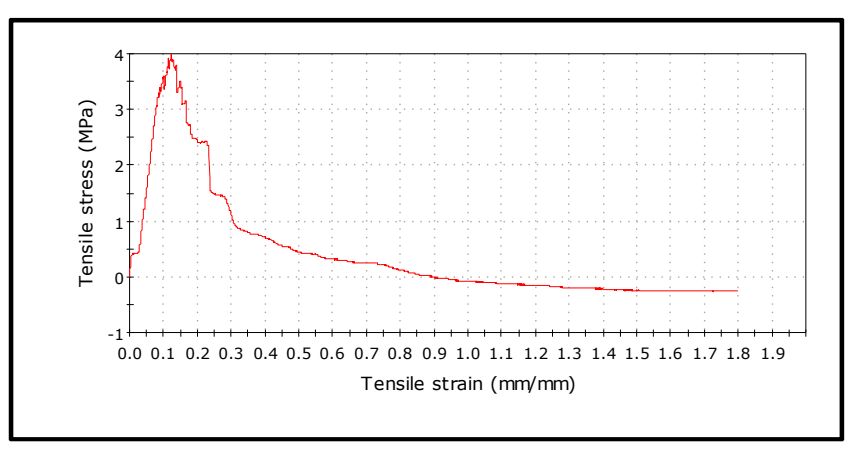

Figure 12. Stress-Strain Curve for Fibre B3.

\subsection{Behaviour of Adhesives on Materials Under Loading}

The behaviour of adhesives on weaved materials were studied under loading. It was observed that topbond adhesive when applied, stuck firmly together the stacked samples of Material B than A. The soft nature and roughness of Material B when compared with A which has possessed thicker nature with smooth surface accounted for this observation. Similar observations were also noticed for Evo-Stik adhesive for each of the materials. The thickness of $2.5 \mathrm{~cm}$ (which was the targeted height for this study) was easy to achieve with Material A as no significant decrease was observed on it during compression unlike Material B where more weaved samples were glued together to achieve $2.5 \mathrm{~cm}$ thickness due to its soft nature. The topbond adhesive was finally observed to possess good bonding strength than Evo-Stik adhesive under loading and this property of topbond adhesive may be attributed to its good viscosity which was lacking in Evo-Stik adhesive.

\section{Conclusion}

Some basic engineering properties of fibres extracted from thaumatococcus daniellii plant using Topbond and Evo-Stik as adhesives have been assessed in this study. Based on the tests carried out, the following conclusion can be drawn from this study:

i. The average moisture content obtained for Fibre $\mathrm{A}$ is lower than for Fibre B. Fibre A therefore makes a better choice since it has a lower moisture content compare to Fibre B.

ii. From the water absorption test, the treated Fibres A for both materials with Topbond adhesives possess lower water absorption rates when compared with treated Fibres B of both materials. This was as a result of the effect of chemical treatment carried out on samples of Fibres A and B which served as inhibitor for water to be absorbed. On the other hand, the untreated fibres of both samples for Evo-Stik adhesive possess high water absorption rates when compared with the treated fibres. Therefore, Topbond bonded fibre samples that is treated can be taken as the most optimum sample that has the greatest tendencies for better performance during usage.

iii. Materials subjected to acetylation pre-treatment and treatment possess high flexural thoughness and tensile strengths as the treatment further improved the fibres thus offering solution for minimizing degradation of natural fibres during extraction and conversion.

iv. Materials bonded with Evo-Stik have low ignition time compared to the ones bonded with Topond.

v. Under loading, Topbond gum shows a good bonding strength than Evo-Stik gum when compared with it and this property of Topbond gum was attributed to its good viscosity property.

The comparison between the two fibre types in addition to the adhesives used shows some correlation in their properties. However, fibre sample A has more satisfactory results than fibre sample B hence making it the best choice of material from the two fibres from thaumatococcus daniellii plant.

\section{Acknowledgements}

The authors wish to appreciate the entire staff of Engineering Material Development Institute (EMDI) in Akure for their support. The immense contribution of Engr. M. P. Akande of the Department of Civil Engineering, Federal University of Technology, Akure during the laboratory test is highly appreciated. 


\section{References}

[1] Singha, A. S. and. Thankur, V. K. (2008): Saccharum Cilliare Fiber Reinforced Polymer Composite. Journal of Chemistry, 5 (4):78.

[2] Wirand (2016): Current Development in Fibre Reinforced Concrete. Composite Science and Technology. 57: 956-968

[3] Parveen, K. and Mohit, T. (2017). Different Types of Fibres Used in Fibre Reinforced Concrete. International Journal of Advanced Research in Computer Science, 8 (4): 380-383.

[4] Sai, U. V. and Ajitha, B. (2017). Concrete Reinforced with Coconut Fibers. International Journal of Engineering Science and Computing. 7 (4): 10436-10439.

[5] Ajiboye, A. V., Lasisi, K. H., and Babatola, J. O. (2018). Evaluation of effect of sodium hydroxide solution on biogas yield of anaerobic digestion of poultry waste and the digestate. International Journal of Energy and Water Resources, 2: 2331 .

[6] Wambua, P., Iven, J. and Verpoest, I. (2003): Natural Fibres: Can they replace glass in fibre reinforced plastics, Composite Science and Technology. 63: 1259-1264.

[7] Nishino, T. Hirao, K. and Inagaki, H. (2004). Kenaf reinforced biodegradeable composite. Composites, Science and technology, 63: 1281-1286.

[8] Aziz, S. H. and Ansell, M. P. (2004). The Effect of Alkalization and Fibre Alignment on the Mechanical and Thermal Properties of Kenaf and Hemp Bast Fibre Composites: Part I- Polyester resin matrix, Composites, Science and technology 64 (9): 1219-1230.

[9] Zainudin, E. S., Sapuan, S. M. and Mohamad, T. M. (2009), Mechanical Properties of Compression Moulded Banana Pseudostem filled, Unplasticized Polyvinyl Chloride Composite. Polymer Plastic Technology and Engineering, 48: 97-101.

[10] Alvarez V. A., Ruscekaite R. A. and Vazquez A. J. (2003). Mechanical properties and water absorption behaviour of composites made from a biodegradable matrix and alkaline treated sisal fibres. Journal of Composite Materials, 37: 15751588 .

[11] Nwonuma, C. O., Irokanulo, E. O. Iji, C. E. Alejolowo, O. O. and Adetunji, C. O. (2016). Effect of Thaumatococcus danielli leaf rat-feed on potassium bromate induced testicular toxicity. Asian Pac. J. Reprod., 5: 500-505.

[12] Adeogun, O., Adekunle, O. A. and Ashsfa, A. (2016). Chemical composition, lethality and antifungal activities of the extracts of leaf of Thaumatococcus danielli against foodbourne fungi. Beni-Seuf Univ. J. Basic Applied Sci., 5: 356-368.

[13] Adedosu, O. T., Badmus, J. A. Adeleke, G. E. and Olalere, G. O. (2017). Thaumatococcus danielli extract modulates glibenclamide activity and ameliorates heamatological disorders, oxidative stress and dyslipidemia associated with diabetes mellitus in rats. Br. J. Pharm. Res., 16: 1-12.

[14] Segun, A. A., Samuel, F. O. and Aminat, A. T. (2015). Assessment of antibacterial activity of essential oil extracted from leaves of Thaumatococcus danielli (Benn) Benth. In light of its inhibitory inpact on extracellular protesase of Shigella dysenteriae. Int. J. Biochem.

[15] Oluwatayo, I. B. and Ojo, A. O. (2014). Socioeconomic contributions of neglected and underutilized species to livelihood security in rural southwest Nigeria: Thaumatococcus danielli as a test case. Mediterr. J. Social Sci., 5: 311-317.

[16] Oluwadare, A. O. (2016). Pulpsheet properties of soda pulp of miraculous berry (Thaumatococcus danielli Benth) stalk as a global fibrous raw material for papermaking. Egerton $J$. Sci. Technol., 15: 190-203.

[17] Oluwadare, A. O. and Gilbert, A. F. and Sotannde, O. A. (2014). A comparison of soda and soda-ethanol pulps of Thaumatococcus danielli Benth (Miraculous Berry) stalks. $B r$. J. Applied Sci. Technol., 4: 2181-2193.

[18] Boadi, S., Baah-Acheamfour, M., Ulzen-Appiah, F. and Jamro, G. M. (2014). Non-timber forest product yield and income from Thaumatococcus danielli under a mixed tree plantation system in Ghana. Int. J. for Res., 10.1155/2014/524863.

[19] Olabanji, S. O., Osinkolu, G. A., Pelemo, D. A., Obiajunwa, E. I. and Oladele, A. T. (2014). PIXE analysis of Thaumatococcus danielli in Osun State of Nigeria. Nuci. Instruments Methods Phys. Res. Sect. B: Beam Interact. Mater. Atoms, 318: 182-186.

[20] Raw Materials Research Development Council (RMRDC) (2004). Bamboo production and utilization in Nigeria, RMRDC publication, August 2004 Edition.

[21] Ogunleye, A. (2016). Mat weaving of Thaumatococcus danielli plant fibre obtained locally in Nigeria. Unpublished Bachelor Degree Dissertation submitted to the Department of Industrial Design of the Federal University of Technology, Akure, Nigeria. Pp. 24-42.

[22] Anike, D. C., Onuegbu, T. U., Ugochukwu-Aniefuna, A. A., Ezuh, C. S. (2015). Comparison of Acetylation and Alkali Treatments on the Physical and Morphological Properties of Raffia Palm Fibre Reinforced Composite. Science Journal of Chemistry, 3 (4): 72-77.

[23] ASTM D8171-18, Standard Test Methods for Density Determination of Flax Fiber, ASTM International, West Conshohocken, PA, 2018, www.astm.org.

[24] ASTM C293-02, Standard Test Method for Flexural Strength of Concrete (Using Simple Beam With Center-Point Loading), ASTM International, West Conshohocken, PA, 2002, www.astm.org.

[25] ASTM E119-07, Standard Test Methods for Fire Tests of Building Construction and Materials, ASTM International, West Conshohocken, PA, 2007, www.astm.org.

[26] ASTM D3039 / D3039M-17, Standard Test Method for Tensile Properties of Polymer Matrix Composite Materials, ASTM International, West Conshohocken, PA, 2017, www.astm.org.

[27] ASTM D4442-07, Standard Test Methods for Direct Moisture Content Measurement of Wood and Wood-Base Materials, ASTM International, West Conshohocken, PA, 2007, www.astm.org. 